\title{
Chapter 4: Multicultural Integration in Political Theory
}

\author{
Geoffrey Brahm Levey
}

The mass migrations to the United States from the 1880 s to 1920 inspired a wealth of influential work by sociologists, historians, and public intellectuals on the integration of people arriving in a new society from the corners of the globe. People such as Israel Zangwill, Randolph Bourne, Horace Kallen, Oscar Handlin, Will Herberg, John Higham, Nathan Glazer and Milton Gordon ${ }^{1}$ helped frame the analysis of immigrant absorption in the United States and beyond. In contrast, political theorists have turned their attention to this subject only recently. There had long been debate over the status of national minorities, going back to J S Mill's ${ }^{2}$ famous warning in 1859 that 'free institutions are next to impossible in a country made up of different nationalities', a position endorsed by T H Green ${ }^{3}$. And this debate became especially energetic among Austro-Marxists (eg, Bauer and others ${ }^{4}$ ) leading up to and following the imperial disintegrations after the First World War. But the subject of immigrant minorities and their integration was largely ignored in political theory for most of the twentieth century.

The English pluralists - J N Figgis, H J Laski and G D H Cole - emphasised the importance of groups such as churches and trade unions as an important check on the state's aggrandisement of power ${ }^{5}$. Similarly, the American pluralists typically had in mind socio-economic interest groups rather than identity groups ${ }^{6}$.

1 Zangwill, Israel (1909). The Melting-Pot: Drama in Four Acts. New York: Macmillan; Bourne, Randolph (1916). 'Trans-National America' Atlantic Monthly 118: 86-97; Kallen, Horace M (1924). Democracy and Culture in the United States. Boni and Liveright, New York; Handlin, Oscar (1951). The Uprooted: The Epic Story of the Great Migrations that Made the American People. Grosset and Dunlap, New York; Herberg, Will (1955). Protestant-Catholic-Jew: An Essay in American Religious Sociology. Doubleday, Garden City, N Y; Higham, John (1955). Strangers in the Land: Patterns of American Nativism, 1860-1925. Rutgers University Press, New Brunswick, N J; Glazer, Nathan and Moynihan, Daniel Patrick (1963). Beyond the Melting Pot: The Negroes, Puerto Ricans, Jews, Italians, and Irish of New York City. MIT Press and Harvard University Press, Cambridge, Mass.; Gordon, Milton M (1964). Assimilation in American Life: The Role of Race, Religion, and National Origins. Oxford University Press, New York.

2 Mill, John Stuart 1972 [1859]. Utilitarianism, On Liberty, and Considerations on Representative Government, H B Acton (ed). J M Dent and Sons, London: 361.

3 Green, T H (1911). Lectures on the Principles of Political Obligation. Longmans, London and New York.

4 Bauer, Otto 2000 [1907]. The Question of Nationalities and Social Democracy. University of Minnesota Press, Minneapolis; Zimmern, Alfred E (1918). Nationality and Government. Robert M McBride and Co., New York; Barker, Ernest (1927). National Character and the Factors in its Formation. Harper and Brothers, New York. 5 Barker, Ernest (1915). Political Thought in England from Herbert Spencer to the Present Day. New York: Henry Holt; Burrow, J W (1988). Whigs and Liberals: Continuity and Change in English Political Thought. Clarendon Press, Oxford; Hirst, Paul (ed) (1989). The Pluralist Theory of the State: Selected Writings of G D H. Cole, $J$ N Figgis and H $J$ Laski. Routledge, London.

6 See, for example, Bentley, Arthur F (1908). The Process of Government. Principia Press, Bloomington, Ind.; Truman, David B (1951). The Governmental Process. Knopf, New York; Schattschneider, E E (1960). The Semi- 
And philosophical pluralists such as Isaiah Berlin ${ }^{7}$ were concerned with the incommensurability of values, and not groups at all. Although multiculturalism as a public philosophy was inaugurated in Canada in 1971, and in various other countries (including Australia) later in the seventies and eighties, there is no entry for it in the corrected edition of the Blackwell Encyclopedia of Political Thought two decades later ${ }^{8}$. For the most part, post-war political theorists assumed either that the 'state should treat cultural membership as a purely private matter', or - as in the early work of John Rawls ${ }^{9}$ and Ronald Dworkin ${ }^{10}$ - that liberal democracies were simplified nation-states, 'where the political community is co-terminous with one and only one cultural community' ${ }^{\prime 1}$.

This situation began to change in the 1980s with the so-called communitarian challenge. Communitarian critics argued that liberalism concentrated on the relationship between the individual and the state to the exclusion of ethnic groups and other collectivities, and that liberal individualism was fundamentally hostile to constitutive identities ${ }^{12}$. In the 1990s, however, and partly in response to the communitarian critique, the debate over cultural identity and recognition was increasingly conducted within the terms of liberal theory. A key impetus, here, was Will Kymlicka's ground-breaking book, Liberalism, Community and Culture, published in 1989. Kymlicka supplied an argument showing how respect for individual autonomy and the other terms of Rawls's ${ }^{13}$ egalitarian liberal theory of justice could actually mandate the recognition of cultural identity and minority cultural rights. Still, even Liberalism, Community and Culture had no index entry for 'multiculturalism'; Kymlicka, a Canadian, was initially concerned with the plight of the Indigenous peoples in his country. However, within a few years, he and other political theorists were addressing the

Sovereign People. Holt, Rinehart and Winston, New York; and Dahl, Robert A (1967). Pluralist Democracy in the United States: Conflict and Consent. Rand McNally, Chicago. For two contrasting interpretations of American pluralism, see Walzer (1980). 'Pluralism: A Political Perspective'. In The Harvard Encyclopedia of American Ethnic Groups, Stephen A (ed) Thernstrom. Harvard University Press, Cambridge, Mass.; and Gunnell, John G (2004). Imagining the American Polity: Political Science and the Discourses of Democracy. Pennsylvania State University Press, University Park.

7 Berlin, Isaiah (1969). Four Essays on Liberty. Oxford University Press, Oxford and New York.

8 Miller, David, Coleman, J, Connolly, W and Ryan, A (eds) (1991). Blackwell Encyclopedia of Political Thought. Basil Blackwell, Oxford.

9 Rawls, John (1971). A Theory of Justice. Harvard University Press, Cambridge: Mass.

10 Dworkin, Ronald (1985). A Matter of Principle. Harvard University Press, Cambridge, Mass.

11 Kymlicka, Will (1995). Multicultural Citizenship: A Liberal Theory of Minority Rights. Oxford: Clarendon Press: 53; Kymlicka, Will (1989). Liberalism, Community and Culture. Clarendon Press, Oxford: 177.

12 For example, Van Dyke, Vernon (1977). 'The Individual, the State, and Ethnic Communities in Political Theory'. World Politics 29: 343-69; Van Dyke, Vernon (1982). 'Collective Entities and Moral Rights: Problems in Liberal-Democratic Thought'. Journal of Politics 44: 21-40; Sandel, Michael J (1982). Liberalism and the Limits of Justice. Cambridge: University of Cambridge Press; Svensson, Frances (1979). 'Liberal Democracy and Group Rights: The Legacy of Individualism and its Impact on American Tribes'. Political Studies 27: 421-39; Taylor, Charles (1985). 'Atomism'. In Philosophical PapersVol. 2:Philosophy and the Human Sciences. Cambridge University Press, Cambridge.

13 Rawls, John (1971). Op cit. 
situation of immigrant minorities ${ }^{14}$. By the turn of the century, multiculturalism and ethno-cultural diversity - covering migrant groups as well as national and Indigenous minorities - had become one of the main research areas in the field ${ }^{15}$. The recent Oxford Handbook of Political Theory ${ }^{16}$, for example, devotes an entire section of four chapters to aspects of cultural identity, including one on multiculturalism.

The point of departure for much multicultural political theory - liberal and anti-liberal alike - is the recognition that the ethno-cultural neutrality of liberal democracies is a fiction. All liberal democracies - including the standard exemplar of state 'benign neglect', the United States - privilege particular cultural practices and traditions. They insist on a particular language or languages as the lingua franca of state business and societal intercourse, organise their year in terms of a particular calendar, recognise certain public holidays; prescribe what narratives are taught as history; and draw on particular cultural motifs and stories for the official symbols, insignia, flags and anthems of the state. Some have goneand do go - much further than this in mandating particular cultures. Many multiculturalists believe that this cultural privileging - typically, of a majority group - warrants some redress for cultural minorities who are also members of the political community, if only to smooth the integration process.

In this paper, I propose to put aside the specific normative arguments in defence of multiculturalism and consider instead its implications for national integration and identity ${ }^{17}$. This issue tends to occasion the most public anxiety and debate over multiculturalism in Australia. Certainly, it is not hard to see why many people think multiculturalism is at odds with national integration. So it is important to analyse whether there is a way of preserving the value of national-cultural identity whilst also accommodating cultural difference. The Australian debate on national identity and cultural diversity has mostly been concerned with the questions of whether there is a national culture and identity, and, if so, what their content is or should be. I want to argue that there are also important questions of where, when and how national culture, identity and character should apply. Let me begin by teasing out the assumptions of the main contending positions in the Australian debate.

14 For example, see Kymlicka, Will (1995). Op cit.

15 Another influential work of the time was Charles Taylor's essay on the 'politics of recognition': Taylor, Charles (1992). Multiculturalism and the 'Politics of Recognition': An Essay, Amy Gutmann (ed) Princeton, N J, Princeton University Press. Taylor was especially concerned with the status and cultural interests of Quebec. 16 Dryzek, John, Honig, Bonnie and Phillips, Anne (eds) (2006). The Oxford Handbook of Political Theory, Oxford University Press, Oxford.

17 For an overview of liberal and anti-liberal arguments for multiculturalism, see Levey (forthcoming). 


\section{Multiculturalism and national integration}

Three vying approaches frame the public and scholarly discourse on Australian national identity: 'thick' or cultural nationalism, 'thin' or liberal nationalism, and civic or post-nationalism ${ }^{18}$.

On the 'thick' or cultural conception, multiculturalism is considered to be, at best, inapt for Australian circumstances ${ }^{19}$, and, at worst, destructive of Australian national identity and cohesion ${ }^{20}$. Australia is said to have a distinct Anglo-Australian character and identity, which has great capacity to integrate newcomers. Advocates point to the fact, for example, that intermarriage rates across ethnic and mainstream Australians are high, increasing with each generation $^{21}$. 'Thick' conceptions of Australian national identity have the virtue of recognising the deep and abiding influence of Anglo-Australian culture on the institutions and patterns of life in Australia. However, the accounts are problematic in that they tend to do what they accuse Australian multicultural policy of doing - namely, essentialise ethnic group identity and membership, rather than allowing for their internal diversity, dynamism, and hybridity. As John Hirst ${ }^{22}$, historian and chairman of the Commonwealth Government's Civics Education Group (responsible for designing the civics and citizenship program taught in schools), puts the accusation: 'Multicultural policy envisaged a world of distinct ethnic groups. This was more and more make-believe'23.

There is, of course, some validity to this claim. Attempts to administer resources to cultural groups will perforce invite the problems of group definition and intra-group hierarchy and control ${ }^{24}$. Indeed, Stephen Castles ${ }^{25}$ goes so far as to suggest that Clifford Geertz's 'primordialist notions of ethnicity' found their

18 Another term - 'ethnic nationalism' - is also common in these discussions. However, strictly speaking, ethnic nationalism prescribes common descent as well as a common culture. While such a position was popular in Australia during the heyday of the White Australia policy, most contemporary advocates of an Anglo-Australian national identity are, as we will see, cultural rather than ethnic nationalists.

19 Galligan, Brian, and Roberts, Winsome (2008). 'Multiculturalism, National Identity and Pluralist Democracy: The Australian Variant'. In Political Theory and Australian Multiculturalism, Geoffrey Brahm Levey, ed). Berghahn Books, New York and Oxford.

20 Blainey, Geoffrey (1984). All for Australia. North Ryde: Methuen Haynes; Knopfelmacher, Frank (1982). 'The Case Against Multi-culturalism'. In The New Conservatism in Australia, Robert Manne, (ed) Oxford: Oxford University Press; Windschuttle, Keith (2004). The White Australia Policy. Macleay Press, Sydney: chapter 11 .

21 Galligan, Brian, and Roberts, Winsome (2008). Op cit; Hirst, John (2001). 'Aborigines and Migrants: Diversity and Unity in Multicultural Australia'. Australian Book Review No. 228: 30-35; Windschuttle, Keith (2005). 'It's not a race war, it's a clash of cultures'. The Australian, 16 December.

22 Hirst, John (2001). Op cit: 30.

23 The same claim is made today by the conservative commentators Janet Albrechtsen, Piers Ackerman and Andrew Bolt - albeit, ironically, with the shrill rider that multiculturalism has succeeded in making 'distinct ethnic groups' a reality.

24 Kukathas, Chandran (1992). 'Are there any Cultural Rights?' Political Theory 20, 1: 105-39.

25 Castles, Stephen (2001). 'Multiculturalism in Australia' In The Australian People: An Encyclopedia of the Nation, Its People and Their Origins, James Jupp, (ed) Cambridge University Press, Cambridge: 808. 
way into early Australian multicultural thinking: 'Australian society could be seen as a collection of relatively homogeneous ethnic communities, each integrated by a distinct set of values and cultural practices, interpreted by 'natural leaders' who were usually male and middle-class.' Yet, this picture of Australian multiculturalism is also misleading.

First, even at its most primordial, Australian multiculturalism has never endorsed the kind of culturally autonomous, self-governing communities evidenced elsewhere around the world or imagined by various thinkers, from libertarians ${ }^{26}$ to Austro-Marxists ${ }^{27}$. Nor does it remotely approximate Horace Kallen's ${ }^{28}$ original idea of 'cultural pluralism' for the United States as a 'democracy of nationalities'. Kallen's idea involved territorial 'self-government', and was modelled on the cantons of Switzerland and on 'England [as a] union of [four] nationalities'29. Even the structural pluralism unsuccessfully promoted by early multiculturalist intellectuals, such as Jean Martin ${ }^{30}$, was mild and integrationist compared to worldly conceptions of cultural pluralism ${ }^{31}$. Second, while multicultural policy did turn on some assumption of 'distinct ethnic groups', neither the assumption nor the administration based on it were such as to lock people in or out of ethnic group membership. Third and relatedly, Australian multicultural policy is highly individualistic. The rights to cultural identity and to social justice apply to individual Australians, however they define and practise their cultural identities $^{32}$. So the 'multi' in Australian multiculturalism stands not only for diversity among groups but also within groups.

In contrast, Hirst's analysis treats ethnic groups monolithically, yoking the fate of members of ethnic groups to the choices of their co-ethnics. He cites figures to highlight the increasing assimilation of immigrants across the second and third generations and thus the supposed pointlessness of multicultural policy. For example, among Greeks, '[n]inety per cent of the first generation were Orthodox, 82 per cent of the second; 45 per cent of the third'33. But these figures also show how large proportions of this community in each generation wish to observe their faith and traditions. They beg the question of why these

\footnotetext{
26 For example, Kukathas, Chandran (2003). The Liberal Archipelago: A Theory of Diversity and Freedom. Clarendon Press, Oxford.

27 For example, Bauer, Otto 2000 [1907]. Op cit.

28 Kallen, Horace M (1924). Op cit.

29 Levey, Geoffrey Brahm (2005). 'National-Cultural Autonomy and Liberal Nationalism'. In NationalCultural Autonomy and Its Contemporary Critics, Ephraim Nimni, (ed) Routledge, London: 160-62.

30 Martin, Jean (1981). The Ethnic Dimension: Papers on Ethnicity and Pluralism by Jean Martin, Sol Encel, (ed) Sydney: George Allen and Unwin.

31 Lopez, Mark (2000). The Origins of Multiculturalism in Australian Politics 1945-75. Melbourne University Press, Melbourne: 54-56.

32 Levey, Geoffrey Brahm (2008). 'Multicultural Political Thought in Australian Perspective'. In Political Theory and Australian Multiculturalism, Geoffrey Brahm Levey, (ed) Berghahn Books, New York and Oxford: $1-26$.

33 Hirst, John (2001). Op cit: 30.
} 
people should not be entitled to cultural consideration where necessary and appropriate. Nor is it clear why the cultural interests of present generations should be answered on the basis of the (anticipated) cultural interests of (some among) future generations. Here and now, many immigrants do seek to observe and retain their ethno-religious heritage. Advocates of a 'thick' conception of Australian identity seem to overlook or dismiss such questions because they tend to assume that multiculturalism necessarily denies the reality or importance of Australian culture. As Hirst puts it,

The migrants were and are in no doubt that there is an Australian way of doing things, an Australian culture. This is the second way that the multicultural label for Australia is misleading. It suggests that there is simply diversity; that there is no dominant culture. Migrants who want to get on and be accepted know better ${ }^{34}$.

Now, it is the civic and post-nationalists who are most concerned to deny the reality or political importance of a distinct Australian culture and identity. In many ways their position is the mirror image of the 'thick' conceptions. Whereas the latter see multiculturalism as undermining Australian national identity, civic and post-nationalists believe that invocations of a national identity are antithetical to Australia's cultural diversity, multiculturalism, and/or universal liberal-democratic values. They believe that Australia's commitment to liberal democratic values together with its cultural diversity requires that the state should be neutral with respect to ethno-cultural matters, although they vary in what this means.

Some argue that Australians should simply dispense with the idea of a national identity altogether. For example, in their well-known book Mistaken Identity: Multiculturalism and the Demise of Nationalism in Australia, Stephen Castles and his associates concluded: 'We do not need a new ideology of nationhood... Our aim must be a community without a nation' ${ }^{35}$. On this view, Australian identity should be grounded only in political or civic values, such as toleration, individual liberty, equality, reciprocity, and a commitment to democratic institutions ${ }^{36}$. Others in this camp suggest that Australian identity should be centred rather on the idea or practice of multiculturalism itself ${ }^{37}$. This last idea

34 Ibid.

35 Castles, S, Kalantzis, M, Cope, B and Morissey, M (1992). Mistaken Identity: Multiculturalism and the Demise of Nationalism in Australia, Pluto Press, Sydney: 148.

36 See Horne, Donald (1997). The Avenue of the Fair Go: A Group Tour of Australian Political Thought. Pymble, NSW: Harper Collins; Kalantzis, Mary (2000). 'Multicultural Citizenship'. In Rethinking Australian Citizenship, Wayne Hudson and John Kane, (eds) Cambridge University Press, Cambridge; Kukathas, Chandran (1993a). 'The Idea of a Multicultural Society'. In Multicultural Citizens: The Philosophy and Politics of Identity, Chandran Kukathas, (ed) Centre for Independent Studies, Sydney.

37 Jayasuriya, Laksiri (2005). 'Australian Multiculturalism and the Politics of a New Pluralism'. Dialogue 24, 1: 75-84; Theophanous, Andrew (1995). Understanding Multiculturalism and Australian Identity. Melbourne: Elikia Books; Sydney Morning Herald (2006). 'A glue that keeps Australian society together'. 16 December. 
found expression in the National Multicultural Advisory Council report that prepared the ground for the New Agenda for a Multicultural Australia: 'Australian multiculturalism will continue to be a defining feature of our evolving national identity ${ }^{\prime 38}$. Former Labor Party leader Mark Latham ${ }^{39}$ also picked upon the idea in the 2004 election campaign: 'The challenge is to modernise our multicultural policies, to make them relevant to our multicultural identity'.

Civic and post-nationalist arguments have the virtue of seeking an inclusive definition of Australian identity and culture that acknowledges the cultural diversity of the Australian people. Yet these approaches are flawed and seem destined to fail. First, as Kymlicka ${ }^{40}$, among others, has argued, 'civic nationalism' is a misnomer in that it ignores the many ways in which liberal democratic states already and inevitably endorse particular ethno-cultural traditions, from the language spoken to state symbols and the historical narratives taught in schools. Moreover, the putative 'political' or 'civic' values of democracy, toleration, equality and so on have deep cultural imprints and a jagged, if not always a sharp, cultural edge. The reason that stipulated limits of liberal toleration are often so controversial, for example, is precisely because liberal democratic values are anything but culturally neutral: they are friendly to some cultural traditions, not so friendly to others. In short, 'civic nationalism' overlooks the ethno-cultural dimensions of public institutions in liberal democracies and of the stipulated civic values themselves.

Second, national identity can and does play an important role in generating and sustaining social cohesion, a sense of belonging, and a commitment to the commonwealth. Liberal nationalists rightly argue that all these features are legitimate interests of democratic states ${ }^{41}$. They are features, moreover, that would seem to be all the more imperative in culturally diverse democracies. To reject national identity as obsolete, then, or to define it as if it could be ethnoculturally neutral, is to forsake or to ignore one of the most powerful political forces available for bringing people together as a community.

Attempts to fashion a new Australian identity on multiculturalism itself fare little better. On the face of it, this approach seems to be a category mistake: that is, it mistakes political and administrative measures that variously allow, accommodate, and integrate the realm of diverse identities for an identity itself.

\footnotetext{
38 National Multicultural Advisory Council (NMAC) (1999). Australian Multiculturalism for a New Century: Towards Inclusiveness. Canberra: AGPS: 13-14. Stephen Castles ((2001) Op cit: 811) astutely observes that the NMAC's recommendation that multicultural policy be henceforth called 'Australian multiculturalism' also seemed to be an attempt to generate nationalist sentiment around multiculturalism.

39 Latham, Mark (2004). 'A Big Country: Australia's National Identity'. ALP press release, 20 April.

40 Kymlicka, Will (1995). Op cit; Kymlicka, Will (2001). Op cit.

41 For example, Canovan, Margaret (1996). Nationhood and Political Theory. Cheltenham: Edward Elgar; Kymlicka, Will (2001). Op cit: 20; Miller 1995; Tamir, Yael (1993). Liberal Nationalism. Princeton University Press, Princeton, N J.
} 
Yet all national identities are constructed and imagined ${ }^{42}$, so why not an identity imagined around multiculturalism? The difficulty is at once semantic and symbolic. The American metaphor of the 'melting pot' helps to illustrate what a national identity focused on multiculturalism is up against. According to Ajume Wingo $^{43}$, the image of the melting pot misdescribes American society, since the US population is increasingly a collection of distinct subpopulations, with more diversity between ethnic, linguistic, or cultural groups than within those same groups'. Yet the fact that the 'melting pot' is a myth is irrelevant, he says; what is important is that it offers a powerful symbol of unity that well serves the legitimate interests of American democracy in creating a sense of solidarity.

Compare the Australian case. Australian society and culture are highly integrative - or so we are told. Intermarriage rates are high; the title of 'new Australians' is or was eagerly bestowed on immigrants; the nomenclature of hyphenated identities is still uncommon ${ }^{44}$. 'Multiculturalism', the proposed symbol for Australian identity, is also mythic, on this account, in misdescribing Australian society. Yet, unlike the metaphor of the 'melting pot' in the US, the proposed national myth for Australia semantically conveys diversity and difference rather than unity and solidarity. 'Multiculturalism' lacks the rhetorical resonance of the 'melting pot' for nation-building purposes.

I stress that the difficulty, here, is more rhetorical than substantive. Multiculturalism is, indeed, concerned with integrating a diverse society based on liberal democratic notions of liberty, equality and justice. Nevertheless, it is the case that many Australians are unable to warm to the term. As the National Multicultural Advisory Council ${ }^{45}$ reported, pollster '[Irving] Saulwick's research identified a strong desire for unity in this country. He showed that the concept of multiculturalism raised in many minds an emphasis on separateness rather than togetherness'. By the mid 1990s, even one of the architects of Australian multicultural policy was calling for the term to be dropped, although he continued to support the policies for which it stands ${ }^{46}$. And, of course, the Howard government removed the word from official use in early 2007, a move that has largely been preserved by the Rudd government. For all these reasons, it makes more sense to construe multiculturalism as a set of principles, policies and programs in the service of an Australian national identity than as the locus of that identity itself.

\footnotetext{
42 Anderson, Benedict (1983). Imagined Communities: Reflections on the Origin and Spread of Nationalism. Verso, London.

43 Wingo, Ajume (2003). Veil Politics in Liberal Democratic States. Cambridge University Press, Cambridge: 126.

44 Hirst, John (2001): 31.

45 National Multicultural Advisory Council (NMAC) (1999). Op cit: 96.

46 Zubrzycki, Jerzy (1996), 'Cynics woo the ethnic vote'. The Australian 15 October.
} 
This brings us to the intermediate position of 'liberal nationalists'. Their 'thin' account of national identity acknowledges both the legitimate national interests of liberal democracies and the need to make room for cultural minorities. The debate at this level is largely about the precise calibration of the 'thinness'. The Israeli philosopher, and now politician, Yael Tamir ${ }^{47}$ includes in 'national identity' virtually all the cultural aspects that 'thick', cultural nationalisms do at the level of nation states. However, unlike these other positions, she insists that national self-determination does not require or presuppose political sovereignty or statehood, cultural attachments are matters of individual choice, and members of cultural minorities are just as entitled to express their 'national identity' as are the members of the majority culture. For Kymlicka, 'nationbuilding' in liberal democracies is legitimate where it is limited to creating and maintaining what he calls a 'societal culture':

I call it a societal culture to emphasize that it involves a common language and social institutions, rather than common religious beliefs, family customs, or personal lifestyles... Citizens of a modern liberal state do not share a common culture in such a thick, ethnographic sense... if we want to understand the nature of modern state-building, we need a very different, and thinner, conception of culture, which focuses on a common language and societal institutions ${ }^{48}$.

Kymlicka allows that liberal democracies also engage in nation-building by developing a national media, national symbols and holidays, and memorialising majority group heroes and events, a position shared by David Miller ${ }^{49}$. Others draw the legitimate boundaries of national identity more narrowly; for example, around 'a history [and] a set of legal and political institutions ${ }^{\prime 50}$.

To my mind, liberal nationalist approaches wrongly dismiss, or lose sight of, two important dimensions of national identity. First, liberal nationalists too quickly dismiss the place of 'national character' ${ }^{\prime 51}$. The inclination to do so is understandable enough given the obscene ways in which such notions have been politically exploited or socially expressed in modern history. However, as liberal nationalists know better than most, nationalism itself can serve both illiberal and liberal goals; the task is to distinguish its legitimate roles and uses. The concept of national character is often challenged on the grounds that the attributes highlighted are stereotypical and contradicted by competing images

\footnotetext{
47 Tamir, Yael (1993). Op cit.

48 Kymlicka, Will (2001). Op cit: 18-19.

49 Miller, David (1995). On Nationality. Clarendon Press, Oxford.

50 Kukathas, Chandran (1993b). 'Multiculturalism and the Idea of an Australian Identity'. In Multicultural Citizens: The Philosophy and Politics of Identity, Chandran Kukathas, (ed) Centre for Independent Studies, Sydney: 149 .

51 A notable exception here is David Miller ((1995). Op cit: 25), who includes national character as a component idea of national identity, and equates both with the 'public culture'.
} 
and stereotypes. Consider one of the most celebrated portraits of the Australian character, Russel Ward's The Australian Legend: According to the myth, the 'typical Australian' is a practical man, rough and ready in his manners and quick to decry any appearance of affectation in others ${ }^{\prime 52}$. Chandran Kukathas cites Ward's portrait and then Jonathan King's opposing assessment to the effect that Australians are 'lazy, arrogant, racist, urban money-grabbers who have surrounded themselves with the myth that they are outback heroes ${ }^{\prime 53}$. Joining many other commentators on the subject, Kukathas notes the 'difficulties in trying to tie down any notion of a "national character" and moves on.

And yet, as everyone knows, the French really are different from the Germans. Canadians are different from Americans, and Australians are different from the Brits and even the New Zealanders. Imprinted, as they are, with their national cultures, they tend to exhibit distinctive habits of mind, emotion, and behaving, instantly noticeable to most outsiders. That many nationals do not exhibit their 'national qualities', and that there may be contradictions in the national character or even vying national characters, is neither here nor there; in human affairs, the only surprise should be if it were otherwise. I suspect that liberal nationalists - who tend to travel a lot - might grant this much at a cultural level, but insist that issues of national character should be separated from the state and quarantined from the business of liberal democratic government. However, national character will perforce find expression through a society's governing institutions; how could it not do so? All three schools of thought tend to misunderstand the place of national character. The crucial point about national character is not that it doesn't exist or that it should be quarantined from government or that it should be politically promoted. Rather, the point is that while national character shapes government, government cannot legislate national character; it cannot be the object or intention of political administration without doing it violence. This is because national character is constantly evolving and any deliberate attempt to represent it will wrench out particular aspects, ensuring that the accounts offered can, at best, bear a passing relation to it. The resultant image is bound to be 'absurdly romanticised and exaggerated' ${ }^{54}$, indeed a grotesque.

If national character is not to become national caricature, then it must be left to its own devices. It will find its own expression. Consider, for example, the extraordinary building that is the New Parliament House in Canberra. That ordinary Australians and visitors can walk up grassy banks and literally stand over their political representatives not only exemplifies a characteristic Australian attitude to authority and an egalitarian temper; it emerges from this

52 Ward, Russel (1958). The Australian Legend. Oxford University Press, Melbourne: 1.

53 Kukathas, Chandran (1993b). Op cit: 147-148.

54 Ward, R (1958). Op cit. 
attitude and temper. Or, still at Parliament House, take the public uproar in 2005 that followed a regulation requiring security guards to cease using the expression 'mate' when addressing politicians and the public. An MP taking umbrage at the informality had prompted the move. The public's sense that acceptable norms had been breached came only when the guards were told to be more formal. National character, because it is character, expresses itself just in and through what we do and find 'natural' or acceptable.

The second dimension of national identity that liberal nationalists tend to underplay concerns what may be called the crucible of civil society. Because they seek to render nationalism compatible with liberal democracy, and thus to make room for cultural minorities, liberal nationalists tend to focus mainly on the legitimate boundaries of state action and on access to the public sphere. National cultures, as we have seen, are 'thinned' out in terms of which ethnocultural aspects - typically, a shared language, societal and political institutions, the nation's history and national symbols - are deemed to be appropriate for government involvement. Other cultural aspects - regarding food, dress, speech, surnames, leisure activities and family size - some of which were once pursued by states in their more assimilationist days, are deemed to be the prerogative of ethnic groups or their individual members. Thus, we are presented with two domains culture-wise: a national culture embodied in societal institutions and overseen by the state, and ethnocultures that are the province of immigrant groups and individuals ${ }^{55}$. The possibility that a national culture might also be constructed and fomented among people's relations in civil society seems to be ignored or denied ${ }^{56}$. Hence Kymlicka's remark: 'The 'melting pot' image was never accurate. Immigrants do indeed integrate into common institutions and learn the dominant language, but they remain, visibly, and proudly, distinctive in their ethnic identities and attachments ${ }^{\prime 57}$. Integration, let alone assimilation, is countenanced only in the restricted terms of the lingua franca and societal institutions.

This picture of integration is as unrealistic as the assimilationist model. In Australia, as in other liberal democracies, there are myriads of interactions among immigrant groups and between them and the dominant cultural majority that occur beyond societal institutions, and which result in cultural absorption and integration of one form or another. For obvious reasons, this absorption is mostly in the direction of the patterns of the dominant culture. John Hirst ${ }^{58}$

\footnotetext{
55 Kymlicka ((1995), Op cit) allows that states may harbour more than one societal culture where Indigenous and national minorities are present.

56 Again, David Miller ((1995). Op cit: chapter 5) is the notable exception: although he frames national identity in terms of a public culture, he emphasises the multiple ways in which a public culture is constructed and shaped.

57 Kymlicka, Will (2001). Op cit: 33

58 Hirst, John (2001). Op cit: 30-31.
} 
cites the stories of a Greek husband rejecting his wife's request for the family to acquire a goat as un-Australian, and of a proud Sri Lankan, Bekaboru Kiyanahati Balapan Koyako, coming to the realisation, in meeting other Australians, that he badly needed a shorter name (he chose Kojak). These are great examples of how national cultural integration is mediated also in interpersonal relations in civil society. There are many other examples of the inductive power of AngloAustralian culture at work in civil society, including the norms governing queue-forming, social space, voice-raising, speech turn-taking, spitting and belching, and the polite reluctance to use the car horn on anything but the most urgent occasions. As Mary Kalantzis observes (albeit critically), although designating a 'set of cultural characteristics' as 'Anglo-Australian', 'Anglo-Celtic Australian' or 'mainstream Australian' is problematic in that it 'masks real internal differences, it alludes to certain ways of speaking, thinking, working and being in the world'59.

In Australia, 'Anglo-Australian' culture remains dominant, and one cannot begin to make sense of Australian institutions and life without understanding this much ${ }^{60}$. The mistake, of course, is to think that the integration is always in the direction of the cultural majority. The impact of Aboriginal culture on Anglo-Australian life - including vocabulary, motifs, art, and even the sense of emplacement and connection to the land-is clear, if too little appreciated ${ }^{61}$. Anglo-Australian culture has also been changed in various ways by successive waves of immigrants, from the rise of soccer to a popular sport, to so-called 'new Australian cuisine' (incorporating Asian and continental influences), to the now national preferment of coffee over tea and wine over beer. Judging by the entries in metropolitan telephone directories, the conventions regarding the complexity of surnames have also been greatly extended. So a national culture is also forged in the hurly burly of civil society, as well as via common societal institutions. In subtle ways, the Anglo-Celtic Australian culture of old is becoming an 'Anglo-meltic' one. That is, Anglo-Australian culture, while still dominant, is being modified at the coalface.

Australian national identity, then, is multifaceted and occupies different domains. There are aspects of national identity having to do with Australian character that will naturally affect the way we govern ourselves, but which we can scarcely do anything about without warping them. There are aspects

59 Kalantzis, Mary (2000). Op cit: 108.

60 Given the effects today of globalisation and the US hegemony, the American influence on AngloAustralian culture must also be reckoned with. For a subtle analysis, see Altman, Dennis (2006) 51st State? Scribe, Carlton.

61 Mulcock, Jane (2002). Searching for our Indigenous Selves: Belonging and Spirituality in Anglo-Celtic Australia. PhD Thesis, University of Western Australia; Read, Peter (2000). Belonging: Australians, Place and Aboriginal Ownership. Cambridge University Press, Cambridge; Trigger, David (2008). 'Place, Belonging and Nativeness in Australia'. In Making Sense of Place, Frank Vanclay, Matthew Higgins and Adam Blackshaw, (eds) National Museum of Australia, Canberra. 
of national identity that are duly the province of government, such as the inculcation and transmission of a national language, the teaching of the nation's history, and the establishment of national institutions, holidays and memorials. And there are aspects of national identity that properly belong in the realm of civil society and beyond the business of government, such as how people dress, call themselves, or spend their leisure, what languages they speak to each other, and even in what accent they speak their English. Here, among the myriad relations of Australians, will also be forged the habits and sentiments and character of the Australian people.

I do not mean to suggest that this account of the sites of Australian identity amounts to a radically new model. On the contrary, in differentiating domains of national identity and delimiting those that are and are not the province of government, it is indelibly a version of liberal nationalism. It is a version, however, that accepts that Australian character has a place in national identity and an implicit impact on government, and which recognises that Australian national identity and character will be forged in the relations among people in civil society, and not only by state policy and societal institutions. Protagonists of a 'thick' conception of Australian identity like Hirst are right to note that there is more to Australian culture and identity than merely civic values or a multicultural mélange. However, the question is which aspects of Australian culture and which of its values should define the conditions of membership and govern access to opportunities in the polity. Civic-cum-post-nationalists like Kalantzis ${ }^{62}$ are rightly concerned that Anglo-Celtic ways of 'being in the world' are 'explicitly and implicitly valued and rewarded' across the board in Australian society. However, the answer to inappropriate cultural privileging is not to be found in expunging or denying a place for Australian culture and identity, as if this were even possible, and installing a 'new civic compact' in its stead. Rather, the answer lies in delimiting the domains of national culture and checking the privileging.

In terms of Australian policy, the 1989 National Agenda for a Multicultural Australia presents a very similar approach to Australian identity. It acknowledges the importance of 'our British heritage' in helping 'to define us as Australian'. It emphasises that 'Multiculturalism does not entail a rejection of Australian values, customs and beliefs'. As part of this 'common core', it highlights the 'basic institutional framework of Australian society', including English as the national language, rule of law, democracy, freedom and tolerance of expression, equality of the sexes, and an 'overriding and unifying commitment to Australia'. It expressly excludes from the public definition of Australian identity ethnocultural aspects such as skin color, style of dress, mode of worship, or other languages spoken. And it recognises that the 'Australian way of life' will evolve 
and change over time with the 'changing face of the Australian population', among other influences ${ }^{63}$. The National Agenda has some weaknesses. For example, it does not explain what is meant by an 'overriding commitment' to Australia's interests 'first and foremost', which seems overreaching ${ }^{64}$.

Nevertheless, the National Agenda outshines the subsequent national multicultural policies on the matter of national identity. Both the New Agenda and Multicultural Australia ${ }^{65}$ tie multiculturalism to Australian national identity in a much less differentiated fashion. While they also promote the same core civic values, they emphasise the idea of Australians' 'multicultural identity' and treat the country's British heritage and predominant 'Anglo-Australian' culture as if they were of minor significance, if not antiquarian interest. And, of course, prior to the 1970s, government policy was to do the very reverse and emphasise 'thick' conceptions of national identity in the form of Anglo-conformity above all else. It is to the credit of the architects of Australia's first national statement of multiculturalism that they fashioned such a subtle and sophisticated version of liberal-nationalist integration.

\section{Conclusion}

Multicultural policy sought to create a space in which cultural identity and difference could be seen as legitimate and a part of one's 'being Australian'. Critics assert that such policies simply gave a green light to cultural separatism, and a shared Australian identity was eroded. Even if there is some truth to this claim, it is also the case that national chauvinism and exclusivity can also spawn minority alienation and separatism. Finding the optimal formula for promoting both national cohesion and cultural liberty is thus a challenge. The debate of this conundrum in Australia has tended to oscillate between two counterproductive approaches: one that construes Australian national identity narrowly in Anglo-Australian terms but is applied widely as the standard of acceptability; and one that, in recent years, has perhaps underemphasised the importance of an Australian national identity, or which has come to define such an identity almost in opposition to Anglo-Australian heritage.

In this essay, I have sought to clarify and defend a particular liberal nationalist conception - or perhaps better, map - of national identity for Australian conditions that avoids these equally problematic alternatives. Understood

63 Office of Multicultural Affairs (1989). National Agenda for a Multicultural Australia, AGPS, Canberra: 50-52.

64 Kymlicka, W (2001). Op cit: 173; Levey, Geoffrey Brahm (2001). 'The Political Theories of Australian Multiculturalism'. The University of New South Wales Law Journal 24, 3: 877-878.

65 Commonwealth of Australia (1999). A New Agenda for Multicultural Australia. AGPS, Canberra; Commonwealth of Australia (2003). Multicultural Australia: United in Diversity, AGPS, Canberra. 
multi-dimensionally and as operating across several domains, national identity and character have a legitimate and vital place in Australian politics and society. On this account, Anglo-Australian culture is duly recognised both inside and beyond the sphere of government, but so is the input of non-Anglo-Australians and the evolving nature of Australian identity and character. Suggested, to some extent, in the National Agenda multicultural policy of 1989, something like this multifaceted map of the domains of national identity is also implicitly respected by many Australian political leaders, institutions, and practices today. The controversies arise typically when it is not.

Nevertheless, there is no gainsaying that the term 'multiculturalism' lends itself to controversy and misinterpretation. Indeed, the word has always harboured an ambiguity. On the one hand, the 'ism' was simply meant to designate a broad commitment to the idea of cultural recognition, accommodation, and state support. On the other hand, the 'culturalism' in the word often has been read as signifying distinct and homogeneous cultures to which all else should defer. This is why the term 'interculturalism', which is rather more common in continental Europe than in the Anglophone democracies and has long been preferred to 'multiculturalism' in Quebec ${ }^{66}$, is not much help. The perceived trouble with multiculturalism is not - or not only - that communities do not adequately interact with each other; it is that they exist and interact as if they were monolithic, self-absorbed, and independent units. Having different cultural fiefdoms interrelate with each other as suggested by 'interculturalism' repeats rather than solves the problem. The term 'multiculturalism' will continue, then, to grate on publics and governments. It may be that we will need to speak of 'multicultural integration' or the like instead.

66 For example, Bouchard, Gérard and Taylor, Charles (2008). Building the Future. A Time for Reconciliation. Abridged Report. Montréal: Commission de consultation sur les practique l'accommodement reliées aux differences culturelles. 